\title{
Improvements of the working conditions for physicians and patient safety in emergency departments
}

\author{
Christian Bjurman*1, Samra Mangafic ${ }^{2}$, Martin J. Holzmann ${ }^{3,4}$ \\ ${ }^{1}$ Department of Internal Medicine, Halland's Hospital, Varberg, Sweden \\ ${ }^{2}$ Department of Emergency Medicine, Halland's Hospital, Varberg, Sweden \\ ${ }^{3}$ Functional Area of Emergency Medicine, Karolinska University Hospital, Huddinge, Stockholm, Sweden \\ ${ }^{4}$ Department of Internal Medicine, Solna, Karolinska Institutet, Stockholm, Sweden
}

Received: April 5, 2018

DOI: $10.5430 /$ jha.v $7 \mathrm{n} 4 \mathrm{p} 17$
Accepted: May 21, 2018

Online Published: May 24, 2018

\begin{abstract}
Background: A high staff turn-over and crowding are common problems in emergency departments (EDs). These problems coexist with a gradual decrease in hospital beds per capita. Many emergency physicians report burnout and plan to resign. Therefore, mostly inexperienced physicians, early in their career, are responsible for front-line emergency care.

Methods: Literature review and analysis of work environment in EDs. Based on this, structural and individual measures were proposed in order to optimize the work environment for physicians.

Results: Working conditions in the ED could be improved through modified back-up, checklists/algorithms, increased number of hospital beds, and optimal use of available beds, and a revision of the current shift organization.

Conclusions: We hope that this analysis will prompt a debate that may lead to improvements in work satisfaction, resource utilization and quality of care.
\end{abstract}

Key Words: Emergency department, Working conditions, Checklists, Patient flow, Crowding, Shift organization

\section{INTRODUCTION}

The evolution of emergency medicine (EM) as a specialty has concurred with dramatic increases in emergency department (ED) visit rates, in the United States, Canada, Sweden and many other countries in the world. ${ }^{[1]}$ There are also signs of increased ED crowding in many countries, and hospitals have therefore implemented different interventions in order to reduce crowding. ${ }^{[1]}$

In Sweden, like in many other countries, emergency care is provided by larger hospitals with EDs staffed with a variety of specialists, including an increasing number of emergency physicians. ${ }^{[1]}$ However, after 5 o'clock p.m., EDs are usually staffed only with inexperienced physicians, like interns or residents in the beginning of their training, with senior physicians not in the hospital, but available over telephone for counselling. Usually, separate physicians are responsible for internal medicine patients, surgery and orthopedic patients, something that is gradually changing as emergency physicians take over more responsibility. To become an emergency physician in Sweden, at least 5 years of training (after becoming a licenced physician), is required, including also service outside the ED, for instance in intensive care and internal medicine wards.

The Public Swedish National Health Care System is funded by taxes, with an additional small copayment at the time of each visit. ${ }^{[1]}$ Healthcare coverage in Sweden is univer-

\footnotetext{
*Correspondence: Christian Bjurman; Email: christian.bjurman@ regionhalland.se; Address: Department of Internal Medicine, Halland's Hospital, Varberg, Sweden.
} 
sal, thus all residents, including expatriates, have access to publically financed healthcare services. ${ }^{[2]}$ There is also an extensive general practioner network in place, taking care of non-urgent care. ${ }^{[1]}$

Many emergency physicians, in Sweden and in other countries, report burnout ${ }^{[3]}$ and many plan to resign. ${ }^{[4]}$ Different emergency physician projects have been discontinued ${ }^{[5,6]}$ due to limited resources. Working conditions have sometimes been considered so poor that assistance from external authorities have been sought. ${ }^{[7]}$ We have identified nine factors, partly related, that alone and in combination contribute to reduced work satisfaction in EDs:

(1) crowding $^{[8]}$ and high work load

(2) inadequate support from senior colleagues ${ }^{[9]}$

(3) work under time constraints ${ }^{[10]}$

(4) limited amount of beds for hospital admissions and observation $^{[11]}$ and therefore responsibility to identify a large proportion of patients that safely can be sent home

(5) limited staffing ${ }^{[12]}$

(6) deficient shift work organization (limited sleep during night shifts, ${ }^{[13,14]}$ extended shifts, and limited recovery time and time lag between shifts)

(7) undersized facilities ${ }^{[12]}$

(8) inadequate clinical skills ${ }^{[15]}$ (also among subspecialists that should act as general backup over telephone but usually work within highly specialized fields)

(9) requirements for high quality standard of care, ${ }^{[16]} \mathrm{de}-$ spite above mentioned limitations.

Perceived stress in the ED can be explained by Karasek's demand control model. ${ }^{[17]}$ The model states that high-strain jobs, with high demands and small possibilities to control the work environment, are particularly stressful and increase the risk of ill health, including emotional exhaustion and psychosomatic health complaints. ${ }^{[18,19]}$ The situation with little control combined with a genuine effort to deliver highquality care may cause mental stress. ${ }^{[20]}$

This has created a vicious circle where EDs are mostly staffed by inexperienced physicians. Symptoms of mental distress are also common among physicians early in their career, ${ }^{[21]}$ coexisting with compulsory service in EM. ${ }^{[22]}$ Despite this, many emergency physicians report high work satisfaction, ${ }^{[23]}$ probably because a selection of physicians less vulnerable to existing stressors will continue working as ED physicians. However, in Sweden, most experienced physicians do not continue working in the ED, thus new and unexperienced physicians in need of support, in order to make safe and efficient decisions, are placed there.
Decision-making in the ED differs from decision-making in hospital wards. ${ }^{[24]}$ Algorithms and checklists for structured work-up in the ED could therefore improve confidence in decision-making and thereby reducing stress and increasing patient safety and optimizing use of existing resources.

Several structural and individual factors that should be reviewed to improve working conditions for physicians in EDs are presented in Figure 1. Some of these factors and additional points are also discussed below.

\section{Methods}

Based on the preceding literature review and own experiences the authors conducted an in-depth analysis of factors, presented in the following sections, that could improve working conditions for physicians and patient safety in EDs.

\section{RESUlts}

\subsection{Patient flow}

EDs should be staffed according to predicted inflow. ${ }^{[25]}$ Estimations can be done based on the following assumptions, apart from historical data and demographic considerations:

(1) Patients tend to start to accumulate (causing crowding) in the ED from 11:00 a.m. ${ }^{[26]}$

(2) Certain diseases like Calicivirus infections and Influenza peak in the winter months, which could then motivate more staff in the ED, due to an increased inflow. ${ }^{\text {[27] }}$

(3) Empirically, it is also common with a higher inflow after certain holidays, like Christmas.

In order to reduce the inflow to the ED, patients should be offered alternatives for evaluation of presumably non-urgent problems. In Sweden, primary care often closes down around 5:00 p.m., and patients also have difficulty getting appointments during office hours, within a reasonable time. ${ }^{[28]}$

It is reasonable to believe that inflow to EDs would be reduced if primary care would offer appointments until 9:00 p.m., also at short notice. Preferably, primary care facilities should be available in close proximity to the ED, and be open around the clock. When patients call an ambulance the ambulance staff should be able to contact primary health care and ideally, together with the patient's regular family physician, decide whether transport to the hospital is necessary or not. Many patients call 1177, a free healthcare advice and referral call service, staffed by nurses. ${ }^{[29]}$ It is sometimes difficult to give tailored recommendations by telephone, therefore often patients are recommended to seek emergency care without an imminent need. Although the 1177 service is intended to reduce visits to the ED, it may be the other way around. 
Artificial decision support systems ${ }^{[30]}$ could potentially assist nurses at the 1177 service and thereby decrease inflow to EDs. Appointments should be available online, for patients to book in primary care, in case of subacute emergencies. Elderly patients in nursing homes could probably often get the care needed without visits to the $\mathrm{ED}^{[31]}$ which commonly would lead to admissions. A family physician could administrate antibiotics at home and, under certain circumstances, directly transfer the patient to a ward for in-hospital care, bypassing the ED. Improved referral indications could also be discussed with family physicians. But also basic medical education in schools and on television could potentially change patients' seeking behavior. For instance, the population should be informed not to seek emergency care in case of common cold or isolated paresthesia in the chest.

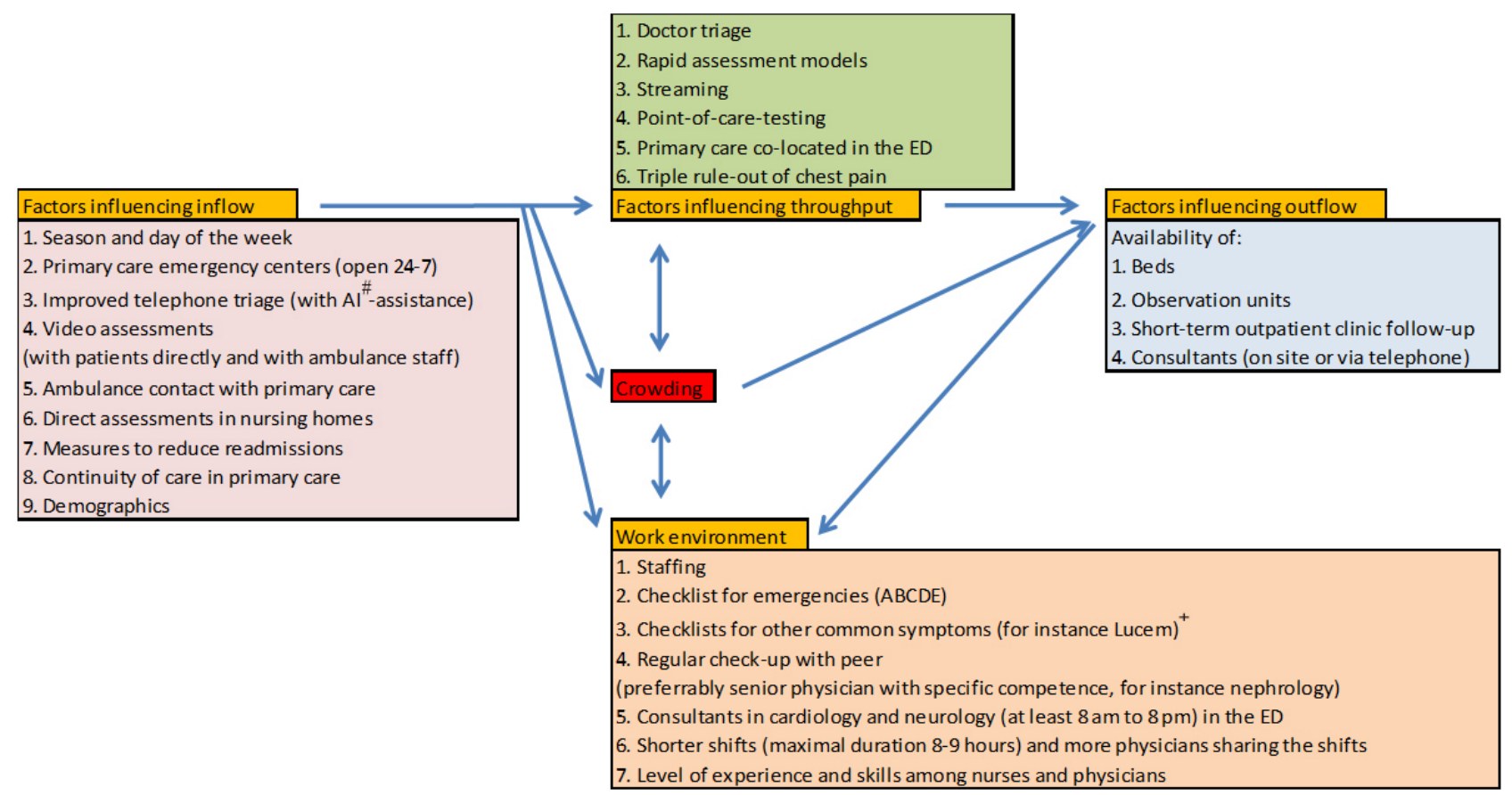

Figure 1. Improved working conditions for physicians in the $\mathrm{ED}^{[32] *}$

${ }^{*}$ The system is appropriate for moderate to large EDs. Modern emergency care requires advanced technology and investments that are impossible for small hospitals to offer (like catheterization laboratory, thrombectomy facilities and intensive care unit). \# AI: Artificial intelligence. ${ }^{+}$Lucem (light or clarity, within the field of EM) checklists. These describe in detail what is important to ask for during history taking and what should be included in the physical examination, specifically for common symptoms encountered in the ED

Throughput in the ED is influenced by the number of available staff and, to a certain degree, their competence and decision-making capacity, crowding, waiting-time for imaging and laboratory data, but also free computers and rooms.

Another approach is to reduce unnecessary imaging, and postpone non-urgent investigations until patients are transferred to a ward. For instance, normally only in first-time seizures, acute brain computed tomography (CT) is indicated. Point-of-care testing has been shown to improve patient throughput, ${ }^{[32]}$ because shorter time to results, but has to be weighed against quality and recalibration of the laboratory method used. Also streaming, thus a specified physician is responsible only for simple patients, has been shown to speed up throughput and to decrease crowding. ${ }^{[32]}$ Finally, outflow is influenced by available beds for admission, risk taking behavior among responsible physicians (decisions on admission or discharge, fear of incidence reports, amount of data collection before final decision), waiting time for transport (to hospital ward, other hospital or home). ${ }^{[33]}$

\subsection{Use of hospital beds}

Sweden, like many other countries, has a shortage of hospital beds. ${ }^{[11]}$ The goal should therefore be to use available hospital beds in an optimal way.

\subsubsection{Alternatives to hospital admission}

Potential alternatives to hospital admission could be:

(1) More observation beds in the ED

(2) Increased possibility to book revisits to appropriate out-patient clinics

(3) Increased possibility to book follow-up to primary care 


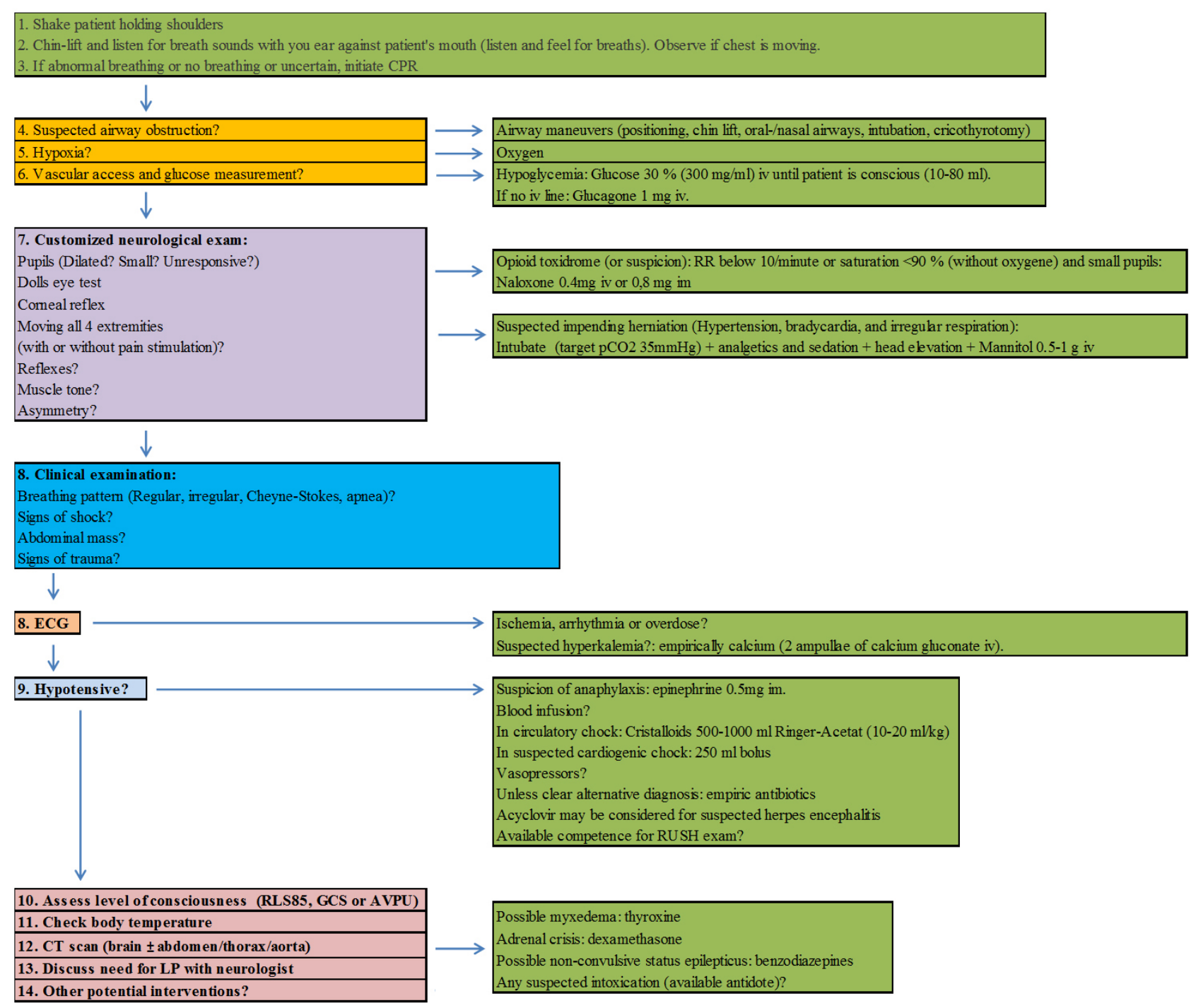

Figure 2. Suggested protocol for unconscious patients. Modified after reference ${ }^{[42]}$ RLS: Reaction Level Scale; GCS: Glasgow Coma Scale; AVPU: Alert, Voice, Pain or Unresponsive

\subsubsection{Better use of available hospital beds}

Elective patients should be admitted to a degree that does not obstruct predicted emergency inflow. ${ }^{[34]}$ Unnecessary admissions could also be reduced by algorithms for safe discharge from the ED, using for example following algorithms:

(1) PESI-score in pulmonary embolism ${ }^{[35]}$

(2) CRB-65 in pneumonia ${ }^{[36]}$

(3) Recurrent seizure does usually not require admis$\operatorname{sion}^{[37]}$

(4) Triple-Rule-Out CT Angiography ${ }^{[38]}$ and troponin algorithms in chest pain ${ }^{[39]}$

(5) Easily available consultations with subspecialists - is there a better solution than admission in the specific patient?

(6) Treatment/Work-up finished in ED? Could reduce need for admission, but there is potential for increased crowding and resource utilization for example imaging.

Patients that are ready for discharge and are waiting for health care planning, establishment of home care or relocation to a nursing home should preferably be transferred to an allocated ward, to free beds on regular wards.

\subsubsection{Increase of available hospital beds}

Different types of beds that are needed are:

(1) More rooms with better monitoring in the ED (can allow for a short observation period, without the need for admission).

(2) Units with observation beds, without highly selective criteria for use, to avoid empty beds.

(3) More general beds in different specialties (can probably reduce readmissions ${ }^{[40]}$ ) in combination with am- 
bition for early discharge before noon, which would require enforced staffing in the wards, preferably a special discharge physician scheduled only for that purpose to reduce ED crowding in the afternoons.

Table 1. Suggested cABCDE protocol for critically ill patients in Swedish EDs. ${ }^{[44-46]}$ Can be modified for use in other countries

\begin{tabular}{|c|c|c|}
\hline Abbreviation & Check-up & Measures \\
\hline \multirow{6}{*}{ Cardiac arrest } & $\begin{array}{l}\text { Shout at the patient. If no response: Pitch arm or shake } \\
\text { patient }\end{array}$ & Initiate cardiopulmonary resuscitation \\
\hline & $\begin{array}{l}\text { Put ear against nose or mouth and listen and feel for } \\
\text { breaths }\end{array}$ & 30 chest compressions: 2 breaths \\
\hline & Unconsciousness, without breathing is cardiac arrest! & Connect automated defibrillator \\
\hline & $\begin{array}{l}\text { Observe! Pulse palpation is excluded in updated } \\
\text { algorithm }\end{array}$ & In VT/VF defibrillate once and then CPR for 2 minutes and renewed ECG analysis \\
\hline & & $\begin{array}{l}\text { If intubated: Continuous compressions while ventilations are given } 8-10 \text { times per } \\
\text { minute }\end{array}$ \\
\hline & & $\begin{array}{l}\text { Stop CPR if patient is breathing normally (or signs of spontaneous circulation) or } \\
\text { no longer medically or ethically motivated }{ }^{\#}\end{array}$ \\
\hline \multirow{8}{*}{$\begin{array}{l}\text { Airway and } \\
\text { spinal control }\end{array}$} & Neck inspection & Remove foreign body \\
\hline & Mouth inspection (foreign body or oedema?) & Oxygen therapy $10-15$ litre/minute \\
\hline & Breath sounds (stridor? obstructivity?) & $\begin{array}{l}\text { Chin-lift or nasopharyngeal airway (size: distance from the tip of the patient's nose } \\
\text { to the earlobe) }\end{array}$ \\
\hline & & $\begin{array}{l}\text { Oropharyngeal airway in unconcious patient (size: distance from corner of the } \\
\text { mouth to the angle of the mandible) }\end{array}$ \\
\hline & & If stridor/oral edema: Adrenaline $0.3-0.5 \mathrm{mg}$ i.m. \\
\hline & & Airway obstructed by the tongue or oral secretions? \\
\hline & & $\begin{array}{l}\text { Position patient on his/her side, suction of the oropharynx and/or insert a nasal } \\
\text { airway. }\end{array}$ \\
\hline & & Betamethasone 10 pills p.o. or $(4 \mathrm{mg} / \mathrm{ml}) 2 \mathrm{ml}$ i.v. \\
\hline \multirow{6}{*}{ Breathing } & Respiratory rate & Oxygen therapy (see above) \\
\hline & Pulseoximetry & Respiratory depression? Ventilation via bag mask or laryngeal mask/intubation? \\
\hline & $\begin{array}{l}\text { Breathing movements (symmetry? depth? accessory } \\
\text { muscles used?) }\end{array}$ & $\begin{array}{l}\text { Salbutamol } 2.5-5-10 \mathrm{mg} \text {, Ipratropium } 0.5 \mathrm{mg} \text { or Terbutaline } 0.5 \mathrm{mg} \text { s.c. } \\
\text { Suspected tension pneumothorax: }\end{array}$ \\
\hline & Breath sounds (prolonged expirium? ronchi? rales?) & Needle decompression, by inserting a 14 or 16 gauge needle into the $2^{\text {nd }}$ intercostal \\
\hline & Blood gas? & \\
\hline & $\begin{array}{l}\text { Waveform capnography (normal } \mathrm{ETCO}_{2} \text { is } 35 \text { to } 45 \\
\mathrm{mmHg} \text { ) }\end{array}$ & \\
\hline \multirow{8}{*}{ Circulation } & $\begin{array}{l}\text { Pulses (frequency? filling? regularity? different } \\
\text { strength?) }\end{array}$ & Two large needles \\
\hline & Blood pressure? & Raise legs \\
\hline & Heart sounds (rate? murmurs? distant tones?) & In anaphylaxia: Adrenaline 0.3-0.5 mg i.m. + Betamethasone $8 \mathrm{mg}$ i.v. + \\
\hline & ECG & Antihistamine p.o./i.v. \\
\hline & & In circulatory chock: Cristalloids $500-1,000 \mathrm{ml}$ Ringer-Acetat $(10-20 \mathrm{ml} / \mathrm{kg})$ \\
\hline & & In suspected cardiogenic chock: $250 \mathrm{ml}$ bolus \\
\hline & & Inotropes? Atropine $0.5 \mathrm{mg}+0.5 \mathrm{mg}$ or external pacing in bradycardia \\
\hline & & $\begin{array}{l}\text { In chest pain/pulmonary oedema: consider nitroglycerin, CPAP, loop diuretics och } \\
\text { morphine }\end{array}$ \\
\hline \multirow{5}{*}{ Disability } & Neck stiffness? & Seizures (after 3-5 minutes: diazepam $10 \mathrm{mg}$ i.v./p.r. ) \\
\hline & Pupil reactions? & $30 \mathrm{ml} 30 \%$ glucose $\times 2$ \\
\hline & Body position, lateralization? & Glucagon $1 \mathrm{mg}$ s.c./i.m./nasally \\
\hline & Consciousness (AVPU or RLS) & Antibiotics? \\
\hline & Glucose & Antidote? \\
\hline \multirow[t]{2}{*}{ Exposure } & $\begin{array}{l}\text { Petechia (meningokcoccus infection?), urticaria, } \\
\text { wounds, signs of trauma }\end{array}$ & Recovery position \\
\hline & Temperature & Blankets \\
\hline
\end{tabular}

Note. ${ }^{*}$ Cordarone $300 \mathrm{mg}$ i.v./i.o. if continuous VF/VT after third defibrillation and add $150 \mathrm{mg}$ i.v./i.o. if VF/VT after fifth defibrillation; ${ }^{\#}$ Coronary angiogram if suspected cardiac etiology and ROSC. Emergency angiogram only in STEMI, LBBB or chest pain in association with cardiopulmonary standstill and concommitant ECG changes indicating ischemia 
Table 2. Exclusion of serious conditions $(\mathrm{A})^{[48]}$

\begin{tabular}{|c|c|}
\hline Chief complain & What should be excluded?* \\
\hline \multicolumn{2}{|c|}{ Possible cardiovascular cause? } \\
\hline \multirow{6}{*}{ Chest pain } & Acute coronary syndrome (compare with previous ECG and troponin level) \\
\hline & Pulmonary embolism \\
\hline & Aortic dissection \\
\hline & Pneumothorax \\
\hline & Caused by infection? \\
\hline & Abdominal cause? \\
\hline \multirow{7}{*}{ Dyspnea } & Upper airway obstruction (sputum-suction?, foreign body, anaphylaxis) \\
\hline & Acute coronary syndrome \\
\hline & Heart failure \\
\hline & Pneumonia \\
\hline & COPD-exacerbation \\
\hline & Pulmonary embolism \\
\hline & Asthma \\
\hline \multirow{3}{*}{ Syncope } & Differentiation, based on history/observations from bystanders between syncope and seizure \\
\hline & Cardiovascular etiology (ischemia, arrythmia, valve disease, tamponade, pulmonary embolism) \\
\hline & Orthostatic etiology (medications, drugs, hypovolemia) \\
\hline \multicolumn{2}{|c|}{ Possible infectious cause? } \\
\hline \multirow{6}{*}{ Fever } & Sepsis \\
\hline & Neutropenic fever? \\
\hline & Influenza \\
\hline & $\begin{array}{l}\text { Infectious focus (erysipelas, pulmonary, uninary tract [pyelonefritis], upper airways, oral/teeth, } \\
\text { ears, brain, needles, wounds, abdomen [peritonitis, diverticulitis, colecystitis, appendicitis], } \\
\text { infectious endocarditis) }\end{array}$ \\
\hline & Pulmonary embolism \\
\hline & Drug-induced fever \\
\hline \multirow{4}{*}{ Diarrhea } & Gastroenteritis (contagious? dehydrated?) \\
\hline & Invasive bacterial syndrome \\
\hline & Sepsis \\
\hline & Gastrointestinal bleeding \\
\hline
\end{tabular}

Note. "Patients without confirmation or suspicion of these conditions can usually be safely discharged from the ED. Some of the mentioned conditions, depending on severity, might only need initiation of treatment and/or observation in the ED before safe discharge. Do not forget symptom relief!

\subsection{Scheduling}

\subsubsection{Improved shift organization}

(1) Shorter shift duration (we suggest max 8-9 hours), also night-time, so that physicians can make better decisions and feel more satisfied at work.

(2) During night-shift, staffing should be planned in the way that physicians can be allowed to go to bed for an hour of sleep in the middle of the night.

(3) More physicians should serve in the ED during work peaks, for example in afternoons, evenings and winter season.

(4) Pay should be offered per patient for a "streaming" physician taking care of simple patients. ${ }^{[41]}$

\subsubsection{Improved back-up}

Senior physicians probably make better decisions than unexperienced and could potentially avoid unnecessary admissions. However, this implies that they have maintained their competence in general EM and have, themselves, gone through a structured EM education. The problem is that today's specialists are usually highly specialized in narrow fields.

We therefore suggest that subspecialists, for common and potentially life threatening conditions (cardiology, neurology, intensivists/emergency care physicians for high priority patients according to triage), when possible, are placed in the ED and infectious disease specialists are available around the 
clock, at least over telephone. Senior colleagues, that should support young inexperienced physicians, should regularly attend emergency courses and also work a couple of weeks each year in the ED. Better back-up also leads to better ed- ucation of new physicians and improved work satisfaction. This might lead to more young physicians pursuing a career in EM in the future.

Table 3. Exclusion of serious conditions $(B)^{[48]}$

\begin{tabular}{|c|c|}
\hline Chief complain & What should be excluded? \\
\hline \multicolumn{2}{|l|}{ Neurology } \\
\hline Neurological deficit & $\begin{array}{l}\text { Stroke/TIA (Indication for thrombolysis or thrombectomy? Assess if carotic or vertebrobasilaris } \\
\text { territory and if cortical or subcortical) } \\
\text { Dissection (aorta, carotis, vertebrobasilaris) } \\
\text { Compressive myelopathy (usually asymmetrical and gradual symptom onset). Usually more } \\
\text { pronounced symptoms in lower extremities. Bladder and bowel function? MRI scan? } \\
\text { Non-compressive myelopathy (inflammatory). May be acute. Usually more pronounced } \\
\text { symptoms in lower extremities. Bladder and bowel function? B12 deficiency? MRI scan? LP? } \\
\text { Sinus thrombosis (CT-angio with venous phase or MRT-angio?) } \\
\text { Borreliosis } \\
\text { Temporal artheritis } \\
\text { Guillain-Barré Syndrome (Relative symmetry + hypo- or areflexia) }\end{array}$ \\
\hline $\begin{array}{l}\text { Progressive weakness in more } \\
\text { than one extremity }\end{array}$ & Myositis \\
\hline Headache & $\begin{array}{l}\text { Subarachnoidal bleed } \\
\text { Bacterial meningitis } \\
\text { Serious intracranial pathology (tumour?) } \\
\text { Temporal artheritis }\end{array}$ \\
\hline Vertigo & $\begin{array}{l}\text { Stroke } \pm \text { dissection } \\
\text { Vestibularis neuritis or bacterial labyrinthitis (inspect ears) }\end{array}$ \\
\hline Visual disturbance & $\begin{array}{l}\text { Stroke? } \\
\text { Retinal detachment } \\
\text { Central retinal artery occlusion? } \\
\text { Temporal artheritis? }\end{array}$ \\
\hline Seizures & Etiology (tumour on CT or MRT, drugs, infections, subtherapeutic doses of antiepileptica) \\
\hline Altered mental status & $\begin{array}{l}\text { Structural (bleedning, stroke } \pm \text { basilaristhrombosis) } \\
\text { Infectious (sepsis, meningitis, herpes encephalopathy) } \\
\text { Electrical (non-convulsive status) } \\
\text { Metabolic (Wernickes encephalopathy or drugs) }\end{array}$ \\
\hline
\end{tabular}

Note. ${ }^{*}$ Patients without confirmation or suspicion of these conditions can usually be safely discharged from the ED. Some of the mentioned conditions, depending on severity, might only need initiation of treatment and/or observation in the ED before safe discharge. Do not forget symptom relief!

\subsection{Structured approach to patients}

We suggest that physicians usually go through the following 9 steps (with additional sub steps) to ensure uniform, standardized and high-quality care in the ED.

(1) Has the patient cardio-pulmonary arrest (unconscious and no or highly abnormal breathing)? Start immediate CPR according to country-specific guidelines.

(2) Is the patient unconscious (but without cardiopulmonary arrest)? Use algorithm, modified for your country, for unconsciousness (see Figure 2). ${ }^{[42]}$

(3) Has the patient another potentially life threatening condition or is the patient deteriorating (or difficult to obtain medical history due to dementia etc.)? Use ABCDE algorithm, with appropriate modifications depending on country (see Table 1). ${ }^{[43-46]}$

(4) Evaluation of vital signs and ECG: Need for immediate percutaneous intervention or immediate therapy (oxygen, fluid, antibiotics [observe allergy], adrenaline).

(5) Background history according to MAPLES (medications, allergies, past medical history [diseases?], life circumstances [for instance living in a nursing home? home alarm?], drug abuse and smoking). ${ }^{[43]}$

(6) Has the patient pain? Pain history according to OPQRST (onset, position, quality, relieving/aggravating, severity, time)..$^{[43]}$ 
(7) Lucem checklists according to chief complain. ${ }^{[47]}$ These describe in detail what is important to ask for during history taking and what should be included in the physical examination, specifically for common symptoms encountered in the ED. ${ }^{[47,48]}$ These checklists are developed in Sweden, but are available in
English for international use.

(8) Routine physical exam + (neurological exam? + special tests)

(9) Checklists to exclude serious conditions (see Tables $2-4),{ }^{[48]}$ common in EDs in Europe, Canada and the United States.

Table 4. Exclusion of serious conditions and management of organ failure ${ }^{[48]}$

\begin{tabular}{|c|c|}
\hline Chief complain & What should be excluded?" \\
\hline \multicolumn{2}{|l|}{ Musculosceletal apparatus } \\
\hline \multirow{3}{*}{ Joint pain } & Septic arthritis? \\
\hline & Gout attack? \\
\hline & Trauma \\
\hline \multirow{5}{*}{ Swollen or painful extremity } & Deep vein thrombosis \\
\hline & Arterial Insufficiency \\
\hline & Infection \\
\hline & Compartment syndrome \\
\hline & Ruptured Achilles tendon \\
\hline Muscle exhaustive symptoms & $\begin{array}{l}\text { Myasthenia gravis (Increased ptosis during } 2 \text { min looking upwards or nasal speech during } 2 \text { min } \\
\text { reading) }\end{array}$ \\
\hline \multicolumn{2}{|l|}{ Other reasons } \\
\hline Intoxikation & $\begin{array}{l}\text { Call Swedish Poisons Information Centre? Exclude conditions with available antidotes. } \\
\text { Evalaute risk for aggressiveness or self-inflicted injury. Children? }\end{array}$ \\
\hline \multirow{2}{*}{ Allergy } & Anaphylaxia \\
\hline & Angioedema \\
\hline $\begin{array}{l}\text { Acute heart failure (with } \\
\text { pulmonary edema) }\end{array}$ & $\begin{array}{l}\text { Immediate PCI if suspected myocardial infarction. Furosemide i.v., } 10-20 \mathrm{mg} \text { in patients not on } \\
\text { diuretics, } 40-80 \mathrm{mg} \text { in patients on diuretics. } 120-160 \mathrm{mg} \text { if no response. Morphine } 5-10 \mathrm{mg} \text { i.v. if } \\
\text { anxiety or pain. CPAP 5-10 } \mathrm{cm} \mathrm{H}_{2} \mathrm{O} \text { (caution if systolic } \mathrm{BP}<90 \mathrm{mmHg} \text { ). Nitroglycerin } \\
\text { sublingual pill or spray (if systolic } \mathrm{BP}>100 \mathrm{mmHg} \text { ). }\end{array}$ \\
\hline Acute renal failure & $\begin{array}{l}\text { Remove nephrotoxic drugs and drugs contraindicated at low GFR. Routine tests: Hb, leucocytes, } \\
\text { thrombocytes, white blood cell (WBC) differential, CRP, sedimentation rate, P-glucose, liver } \\
\text { enzymes och coagulation parameters. Blood gas analysis. } \\
\text { Bladderscan, creatinine (compare with previous level), urea, urat, albumin, Ca, phospate, PTH } \\
\text { och p-standard bicarbonate, urinatry dip stick, U-sediment, U-albumin/creatinine ratio, } \\
\text { U-osmolality and FENa. } \\
\text { Pulmonary x-ray, renal ultrasound (size - hydronephrosis - parenchyma) } \\
\text { Diuretics only if overhydrated. Need for fluid? Urinary catheter (urinary output). Blood pressure } \\
\text { regulation? }\end{array}$ \\
\hline
\end{tabular}

Note. ${ }^{*}$ Patients without confirmation or suspicion of these conditions can usually be safely discharged from the ED. Some of the mentioned conditions, depending on severity, might only need initiation of treatment and/or observation in the ED before safe discharge. Do not forget symptom relief!

\section{Conclusions}

Working conditions in the ED could be improved through modified back-up, checklists/algorithms, increased number of hospital beds, and optimal use of available beds, and a revision of the current shift organization. The included treatment protocols in this article reflect what could be considered Swedish high-quality care, and, when used in other countries, have to be adapted to local circumstances, and country specific treatment traditions.
As most EDs have the same main objectives, primarily to take care of patients seeking emergency care, our collected ideas could certainly be applied to emergency care in most countries, striving for improved quality, logistics, and cutting of costs.

\section{CONFlicts OF INTEREST Disclosure}

The authors declare they have no conflicts of interest. 


\section{REFERENCES}

[1] Pines JM, Hilton JA, Weber EJ, et al. International perspectives on emergency department crowding. Acad Emerg Med. 2011; 18: 135870. PMid: 22168200. https://doi.org/10.1111/j.1553-271 $2.2011 .01235 . x$

[2] Swedish healthcare: all you need to know. [cited 10 May 2018]. Available from: https://www.thelocal.se/20130327/46910

[3] Goldberg R, Boss RW, Chan L, et al. Burnout and its correlates in emergency physicians: four years' experience with a wellness booth. Acad Emerg Med. 1996; 3: 1156-64. PMid: 8959173. https://doi.org/10.1111/j.1553-2712.1996.tb03379.x

[4] Doan-Wiggins L, Zun L, Cooper MA, et al. Practice Satisfaction, Occupational Stress, and Attrition of Emergency Physicians. Academic Emergency Medicine. 1995; 2: 556-63. PMid: 7497060. https://doi.org/10.1111/j.1553-2712.1995.tb03261.x

[5] Bark C. SU/Sahlgrenska får börja om på ruta ett [SU/Sahlgrenska has to start from scratch]. Sjukhusläkaren. [cited 2018 Feb 28]. Available from: http://www.sjukhuslakaren.se/susahlgrenska-far -borja-om-pa-ruta-ett/

[6] Inga akutläkare kvar på lasarettet [No emergency physicians left at the hospital]. Aftonbladet. [cited 28 Feb 2018]. Available from: https : //www.aftonbladet.se/lokala-nyheter/92oXM@ablokal

[7] Lundbäck A. Krisen på akutsjukhusen: »En ohållbar arbetsmiljö« [Crises at emergency hospitals: An unsustainable work environment]. Läkartidningen. [cited 3 March 2018]. Available from: http://www.lakartidningen.se/Aktuellt/Nyheter /2017/01/En-ohallbar-arbetsmiljo/

[8] Yarmohammadian MH, Rezaei F, Haghshenas A, et al. Overcrowding in emergency departments: A review of strategies to decrease future challenges. Journal of Research in Medical Sciences. 2017; 22: 23. PMid: 28413420. https://doi.org/10.4103/1735-1 995. 200277

[9] Bark C. Akutläkarsatsningen knäcktes av brist på ST-block och handledning [Emergency care physican project failed due to shortage of resident physician employments and supervision]. Sjukhusläkaren. [cited 3 March 2018]. Available from: http://www.sjukhuslak aren.se/sjukhuset-i-varberg-hade-tidigt-en-ambitio n-att-utveckla-ett-akutsjukvardskoncept-men-forut sattningarna-var-daliga-och-projektet-havererade/

[10] Väntetider vid sjukhusbundna akutmottagningar - Slutrapport mars 2011 [Waiting times in hospital emergency departments]. Socialstyrelsen. 2011 [cited 7 Feb 2018]. Available from: https://www.socialstyrelsen.se/Lists/Artikelka talog/Attachments/18284/2011-3-36.pdf

[11] Brist på vårdplatser - kris inom svensk sjukvård [Shortage of hospital beds - crisis in Swedish hospital care]. Sveriges läkarförbund. 2004 [cited 7 Feb 2018]. Available from: https://www.slf.se/upload/Lakarforbundet/Tryck saker/PDFer/Vi\%20tycker/brist_vardplatser80.pdf

[12] "För mycket patienter, för lite personal och för lite utrymme". Sjuksköterskors erfarenheter av patientsäkerheten på en akutmottagning ["To many patients, to little staff and limited space"]. Nurses'experiences regarding patient saftey in an emergency department]. Sophiahemmet högskola. 2014 [cited 7 Feb 2018]. Available from: http://www.diva-portal.se/smash/get/diva2: 757495/FULLTEXT01.pdf

[13] Tyssen R, Vaglum P, Gronvold NT, et al. The relative importance of individual and organizational factors for the prevention of job stress during internship: a nationwide and prospective study. Med Teach. 2005; 27: 726-31. PMid: 16451895. https ://doi.org/10.1080/ 01421590500314561

Published by Sciedu Press
[14] Scharfenort S, Löfgren T. Läkares nattjour under jourvecka: Effekter avseende kognitiv funktion, riskutsatthet samt psykosocial och psykosomatisk belastning [Physicians' night shifts during a shift week: Effects on cognitive function, risk exposure and psycosocial and psycosomatic strain]. Available from: http://lup.lub.lu.se/luur/download?func=downl oadFile\&recordOId=3812806\&f ileOId=3992402

[15] Finset KB, Gude T, Hem E, et al. Which young physicians are satisfied with their work? A prospective nationwide study in Norway. BMC Med Educ. 2005; 5: 19. PMid: 15932648. https: //doi.org/10.1186/1472-6920-5-19

[16] Odegard S. The Swedish lex Maria-then and now. Injuries in health care in a historic perspective. Nord Med. 1996; 111: 352-5. PMid: 9110948

[17] Jex S, Kain J. Karasek's (1979) job demands-control model: A summary of current issues and recommendations for future research. I: New Developments in Theoretical and Conceptual Approaches to Job Stress. 2010; 8(41): 237-68.

[18] Karsek RA, Theorell T. Ökad kontroll gör arbetstagare sjukare [Increased control makes employees sicker]. Svenska Dagbladet. [cited 25 March 2018]. Available from: https://www.svd.se/okad-k ontroll-gor-arbetstagare-sjukare

[19] de Jonge J, Dollard MF, Dormann C, et al. The Demand-Control Model: Specific Demands, Specific Control, and Well-Defined Groups. International Journal of Stress Management. 2000; 7: 269-87. https : //doi.org/10.1023/A: 1009541929536

[20] Glasberg AL, Eriksson S, Norberg A. Burnout and 'stress of conscience' among healthcare personnel. J Adv Nurs. 2007; 57: 392-403 PMid: 17291203. http://dx.doi.org/10.1186/1472-6963-1 3-502

[21] Dahlin M, Runeson B. Psykisk ohälsa vanligt bland läkare [Mental illness common umong physicians]. Läkartidningen. [cited 7 Feb 2018]. Available from: http://www. lakartidningen.se/Func tions/OldArticleView . aspx?articleId=12704

[22] Senaste version av Socialstyrelsens föreskrifter (SOSFS 1999:5) om allmäntjänstgöring för läkare [Latest version of The National Board of Health and Welfare's directives (SOSFS 1999:5) for interns. [cited 3 March 2018]. Available from: http://www.socialstyrelsen. se/sosfs/1999-5

[23] Cydulka RK, Korte R. Career Satisfaction in Emergency Medicine: The ABEM Longitudinal Study of Emergency Physicians. Annals of Emergency Medicine. 2008; 51: 714-22.e1. PMid: 18395936. https://doi.org/10.1016/j.annemergmed.2008.01.005

[24] Kovacs G, Croskerry P. Clinical decision making: an emergency medicine perspective. Acad Emerg Med. 1999; 6: 947-52. PMid: 10490259. https://doi.org/10.1111/j.1553-2712.1999.t b01246.x

[25] Nambiar KTM, Nedungalaparambil NM, Aslesh OP. Studying the Variability in Patient Inflow and Staffing Trends on Sundays versus Other Days in the Academic Emergency Department. J Emerg Trauma Shock. 2017; 10: 121-7. PMid: 28855774. https://doi org/10.4103/JETS.JETS_139_16

[26] Väntetider och patientflöden på akutmottagningar. Rapport december 2015. [Waiting time and patient flows in emergency departments. Report from december 2015]. Socialstyrelsen. [cited 5 March 2018] Available from: https://www.socialstyrelsen.se/Lists/A rtikelkatalog/Attachments/19990/2015-12-11.pdf

[27] Luftvägspatogener. Prov analyserade av Karolinska Universitetslaboratoriet till och med vecka 82018 [Airway pathogens. Samples analyzed at Karolinska University laboratory until week 8 2018] Karolinska Universitetslaboratoriet. [cited 5 March 2018]. Available from: https://www.karolinska.se/contentassets/641014 
fb636e4854a3cffe795a2784f4/rapport-influensa--och -rs-virus-och-andra-luftvagspatogener.pdf

[28] Mirsch H. Lång väntan har blivit längre [Long waiting time has further increased]. Vårdfokus. [cited 5 March 2018]. Available from: https://www.vardfokus.se/webbnyheter/2018/febr uari/lang-vantan-har-blivit-langre/

[29] 1177. Cited 5 March 2018. Available from: https://www.1177.s e/

[30] AI och automatisering för första linjens vård [AI and automation of first-line care]. En rapport från Inera $\mathrm{AB}$ och förstudien Digital sjukvårdsrådgivning. [cited 25 March 2018]. Available from: https ://www. inera.se/globalassets/projekt/nya-117 7-vardguiden/ineras-rapport-ai-och-automatiserin g-for-forsta-linjens-vard.pdf

[31] Myredal A, Mauritzon I, Blom M, et al. Many people over 80 years had been able to get care outside the hospital. Lakartidningen. 2016; 113.

[32] Jarvis PR. Improving emergency department patient flow. Clin Exp Emerg Med. 2016; 3: 63-8. PMid: 27752619. https ://doi.org/ 10.15441/ceem.16.127

[33] Tang C, Chen Y, Lee S. Non-clinical work counts: facilitating patient outflow in an emergency department. Behaviour \& Information Technology. 2015; 34: 585-97. https://doi.org/10.1080/014492 9X. 2014.963673

[34] Carpman A. Smartare planering ska vässa arbetsmiljön [More intelligent planning should improve work environemnt]. Dagens medicin. [cited 4 March 2018]. Available from: https://www.dagensmedicin.se/artiklar/2018/02/23/s martare-planering-ska-vassa-arbetsmiljon/

[35] Aujesky D, Obrosky DS, Stone RA, et al. Derivation and validation of a prognostic model for pulmonary embolism. Am J Respir Crit Care Med. 2005; 172: 1041-6. PMid: 16020800. https: //doi.org/10.1164/rccm.200506-8620C

[36] Stralin K, Goscinski G, Hedlund J, et al. Management of adult patients with community-acquired pneumonia. Evidence-based guidelines from the Swedish Infectious Diseases Association. Lakartidningen. 2008; 105: 2582-7. PMid: 18846863

[37] ABC om Akut handläggning av epilepsi [ABC of emergency workup of epilepsy]. Läkartidningen. [cited 5 March 2018]. Available from: http://www.lakartidningen.se/0ldWebArticlePdf /1/15403/LKT1046s2891_2895.pdf
[38] Halpern EJ. Triple-rule-out CT angiography for evaluation of acute chest pain and possible acute coronary syndrome. Radiology. 2009; 252: 332-45. PMid: 19703877. https://doi.org/10.1148/ra diol. 2522082335

[39] Morrow DA. Clinician's Guide to Early Rule-Out Strategies With High-Sensitivity Cardiac Troponin. Circulation. 2017; 135: 1612 6. PMid: 28438803. https://doi.org/10.1161/CIRCULATIO NAHA . 117.026717

[40] Salata BM, Sterling M, Beecy AN, et al. Discharge Processes and 30-Day Readmission Rates of Patients Hospitalized for Heart Failure on General Medicine and Cardiology Services. American Journal of Cardiology. 2018. PMid: 29548676. https ://doi.org/10.1016/ j.amj card. 2018.01.027

[41] Cederberg J. Läkare på ackord ska minska köer till akuten [Physicians working at accord should cut queues in the emergency department] [cited 5 March 2018]. Available from: http://www.lakartid ningen.se/Aktuellt/Nyheter/2018/02/Lakare-pa-ackor d-ska-minska-koer-till-akuten/. Läkartidningen

[42] Morgenstern J. The emergency medicine approach to an unconscious patient. First10EM blog. [cited 5 March 2018]. Available from: https://first10em.com/unconscious/

[43] Sundblom E, Dryver E. ABC om Beslutsfattande på akuten [ABC of decision-making in the Emergency Department]. Läkartidningen. $2013 ; 110$.

[44] The ABCDE approach. Resuscitation Council (UK). [cited 3 March 2018]. Available from: https://www.resus.org.uk/resusci tation-guidelines/abcde-approach/

[45] Linde KB. Akut omhändertagande enligt cABCDE [Emergency care according to $\mathrm{ABCDE}$ ]. [cited 5 March 2018]. Available from: http : //www . internetmedicin. se/page. aspx?id=5855

[46] Advanced Life Support Group. Acute Medical Emergencies. The Practical Approach. Second Edition. Wiley-Blackwell. ISBN 978-07279-1854-3.

[47] Dryver E, Johannsson G, Mokhtari A, et al. Checklistor och »crowdsourcing « för ökad patientsäkerhet på akutmottagningen [Checklists and crowdsourcing for increased patient safety in the Emergency Department]. Läkartidningen. 2014. PMid: 24720026.

[48] Symptom Checklists Version 171120. Lucem. Clarity in Emergency Medicine. [cited 5 March 2018]. Available from: http: //lucem.info/checklists-resusc/blodgas/ 